\title{
A Case of Endocarditis due to Coxiella burnetii
}

\author{
Coxiella burnetii'ye Bağlı Bir Endokardit Olgusu
}

\author{
(1) Selda AYDIN, (1) Okan DERIN, (1) Mesut YILMAZ
}

istanbul Medipol University Faculty of Medicine, Department of Infectious Diseases and Clinical Microbiyology, istanbul, Turkey

\section{Abstract}

A 36-year-old male patient, who was an agricultural farmer and had a diagnosis of bicuspid aortic valve and coarctation, was admitted with symptoms of fever, fatigue, and shortness of breath that lasted for a month, in March 2017. Examination revealed dyspnea and bilateral rales and rhonchi in lung auscultation. A 3/6 systolic murmur was heard in the mesocardiac focus. The laboratory tests showed a white blood cell count of $15.14 \times 10^{3} / \mu \mathrm{l}$, erythrocyte sedimentation rate of $36 \mathrm{~mm} / \mathrm{h}$, and C-reactive protein of $26 \mathrm{mg} / \mathrm{l}$. An echocardiogram showed mobile vegetation ( $30 \times 10$ $\mathrm{mm}$ ) on the aortic valve and severe aortic and tricuspid valve insufficiency. All blood cultures that are taken from the patient with the diagnosis of infective endocarditis were negative and C. burnetii phase I lgG antibody was positive at 1/32768 titer. As far as we know, herein, we present a case of endocarditis due to $C$. burnetii, which is the third case that is reported in Turkey.

Keywords: Culture-negative endocarditis, zoonotic infection

\section{Öz}

Q ateşi, Coxiella burnetii'nin neden olduğu zoonotik bir hastalıktır. Çiftlik hayvanları insan enfeksiyonları için birincil rezervuarlardır. Akut 0 ateşi genellikle grip benzeri bir hastalık olarak ortaya çıkar. Kronik formda ana klinik tablo endokardittir. Otuz altı yaşında erkek hasta, biküspit aort kapağı ve koarktasyon tanısı alan bir tarım çiftçisi, Mart 2017'de bir aydır devam eden ateş, yorgunluk ve nefes darlığı şikayetleri ile başvurdu. Fizik muayenede hasta dispneik olup, akciğer seslerinde bilateral ral ve ronküs mevcuttu. Mezokardiyak odakta 3/6 sistolik üfürüm duyuldu. Laboratuvar

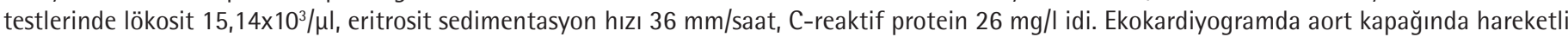
bir vejetasyon (30x10 mm), şiddetli aort ve triküspit kapak yetmezliği saptandı. Enfektif endokardit tanısıyla hastadan alınan tüm kan kültürleri negatif sonuçlandı. C. burnetii faz I lgG antikoru 1/32768 titrede pozitif geldi. Bu makalede bildiğimiz kadarıyla Türkiye'de bildirilen üçüncü olgu olan C. burnetii'ye bağlı endokardit vakasını sunduk.

Anahtar Kelimeler: Kültür negatif endokardit, zoonotik enfeksiyon

\section{Introduction}

0 fever is a zoonotic disease that is caused by Coxiella burnetii, an intracellular, Gram-negative bacterium. Farm animals are usually the primary reservoirs for human infection. Infections classically occur through inhalation of contaminated aerosols directly from birth materials of infected animals, consumption of milk and dairy products, and skin contact. Acute 0 fever usually presents as an influenza-like illness. In the persistent focalized form (formerly chronic 0 fever), the main clinical manifestation includes endocarditis, wherein 0 fever endocarditis involves 60 $78 \%$ of all chronic 0 fever cases $^{[1-3]}$. 0 fever has been known in our country since 1947 . In addition to sporadic cases, it has been detected as an epidemic in some geographical regions from time to time ${ }^{[4]}$. Seroprevalence studies that are conducted in our country have been designed as the general population or risk groups (veterinarians, slaughterhouse butchers, farmers, butchers, milk and dairy products producers, etc.) in the different geographic regions and, seroprevalence varies between $8 \%$ and $7 \% 0^{[5-8]}$. Seropositivity in animals varies between $5 \%$ and $2 \% 0^{[4]}$. Seroprevalence in the European countries varies between 2.4\%

Cite this article as: Aydın S, Derin 0, Yılmaz M. A Case of Endocarditis due to Coxiella burnetii. Mediterr J Infect Microb Antimicrob. 2022;11:9.

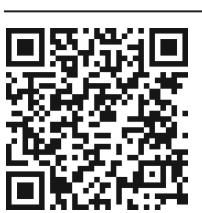

Address for Correspondence/Yazışma Adresi: Selda Aydın MD, İstanbul Medipol Universitesy Faculty of

Medicine, Department of Infectious Diseases and Clinical Microbiyology, İstanbul, Turkey

Phone: +90 5322032754 E-mail: seldaaydin@medipol.edu.tr ORCID ID: orcid.org/0000-0002-3131-442X

Received/Geliş Tarihi: 31.07.2021 Accepted/Kabul Tarihi: 29.11.2021

-Copyright 2022 by the Infectious Diseases and Clinical Microbiology Specialty Society of Turkey

Mediterranean Journal of Infection, Microbes and Antimicrobials published by Galenos Yayınevi. 
and $83.7 \%$ according to countries and risk groups ${ }^{[9]}$. Herein, we present a case of endocarditis due to $C$. burnetii, which is the third case reported in Turkey.

\section{Case Report}

A 36-year-old male patient, who was diagnosed with bicuspid aortic valve and coarctation and patent foramen ovale, was admitted with symptoms of fever, fatigue, and shortness of breath that lasted for a month, in March 2017. He was an agricultural farmer and his past medical history was unremarkable. On examination, he was well-oriented and cooperative but fatigued and exhausted. His blood pressure was $116 / 65 \mathrm{mmHg}$, respiratory rate was 20 breaths/minute, and was tachycardic with a pulse rate of $105 \mathrm{bpm}$. He was dyspneic, with bilateral rales and rhonchi in the lung bases. A 3/6 systolic murmur was heard in the mesocardiac focus with the presence of S1 and S2 and he had abdominal distention, hepatomegaly, and ascites.

The laboratory tests showed normocytic normochromic anemia with hemoglobin of $7.7 \mathrm{~g} / \mathrm{dl}$, white blood cell count of $15.14 \times 10^{3} /$ $\mu \mathrm{L}$, and normal platelet counts. The liver and kidney function tests were normal. His erythrocyte sedimentation rate (ESR) was $36 \mathrm{~mm} / \mathrm{h}, \mathrm{C}$-reactive protein (CRP) was $26 \mathrm{mg} / \mathrm{l}$, and rheumatoid factor was $613 \mathrm{U} / \mathrm{ml}$. The Rose Bengal and standard tube agglutination tests were negative. Based on his presentation and clinical findings, infective endocarditis was suspected, thus three sets of blood cultures were drawn and vancomycin and ampicillin-sulbactam were empirically commenced.

The transthoracic echocardiogram and transesophageal echocardiogram showed mobile vegetation $(30 \times 10 \mathrm{~mm})$ on the aortic valve, severe aortic and tricuspid valve insufficiency, pulmonary hypertension, and pericardial effusion. Abdominal ultrasonography showed hepatosplenomegaly (liver of 216 $\mathrm{mm}$, spleen of $155 \mathrm{~mm}$ ), pleural effusion, and hepatic venule dilation. All blood cultures that are taken before antibiotic treatment remained negative. When the negative blood cultures were observed, serological tests for C. burnetii and Bartonella henselae were requested for culture-negative endocarditis. The general condition of the patient became worse during the $2^{\text {nd }}$ week of empirical treatment. Dyspnea increased and tachypnea and jaundice developed. The liver function tests and creatinine levels were elevated. At the end of the second week, $B$. henselae $\lg G$ negative and $C$. burnetii phase I IgA was positive, and phase II IgG, phase II IgM, and phase I IgG antibodies were positive at $1 / 16384,1 / 96$, and 1/32768 titers, respectively. C. burnetii DNA was also positive by polymerase chain reaction (PCR). The treatment of the patient was changed to doxycycline $2 \times 100$ $\mathrm{mg} /$ day and hydroxychloroquine $3 \times 200 \mathrm{mg} /$ day orally. His clinical condition and laboratory findings improved in a week and underwent aortic valve replacement and tricuspid valve and ventricular aortic fistula repair. The patient was discharged on the $15^{\text {th }}$ day postoperatively. He received treatment for two years. At thirty-six months after the operation, the patient was alive, and well with no sign of recurrent infection and a negative titer of antibody.

\section{Discussion}

Blood culture-negative infective endocarditis (BCNIE) refers that no causative microorganisms can be grown using conventional blood culture methods. BCNIE accounts for 5-10\% of all endocarditis cases. Agents in these cases are usually intracellular microorganisms, such as Coxiella spp., Legionella spp., Bartonella spp. and Mycoplasma spp. ${ }^{[10]}$. The seroprevalence of C. burnetii ranges from $1 \%$ to $70 \%$ worldwide and in Turkey ${ }^{[7,11-13]}$. Karabay et al. ${ }^{[14]}$ reported the seroprevalence of $C$. burnetii in our country as $23.8 \%$ in the rural area of Bolu, in the adult people. Eyigör et al. ${ }^{[15]}$ determined the seroprevalence of Coxiella as $42.3 \%$ in the risk group in Aydın. Seroprevalence was 39.3\% and $32.3 \%$ in blood donors in İzmir and Ankara, respectively ${ }^{[16,17]}$. Persistent focalized 0 fever occurs in $<5 \%$ of people with acute infection and most commonly presents as infective endocarditis or vascular infections ${ }^{[18]}$. Predisposing factors of persistent focalized 0 fever are immunosuppression, preexisting heart or vascular conditions, and preexisting valvulopathy ${ }^{[19]}$. Our case was a farm worker who had preexisting cardiovascular issues including bicuspid aortic valve and coarctation, and patent foramen ovale.

The diagnosis of 0 fever may be delayed since it can mimic a lot of diseases. Serological tests were requested for $C$. burnetii and $B$. henselae in the patient whose blood cultures were negative in terms of culture-negative endocarditis. C. burnetii has two antigenic phases. The phase II IgG antibody titer is high in acute infection, whereas the phase I lgG titer is raised in chronic infection. The presence of an $\lg G$ phase I titer of $>1 / 800$ is considered for diagnosis ${ }^{[20]}$. Our case had a phase I IgG titer of $1 / 16384$ and $C$. burnetii DNA was positive in his whole blood sample by PCR. Antibodies of $B$. henselae were negative.

Doxycycline is preferred in combination with a quinolone, such as ciprofloxacin, rifampicin, or hydroxychloroquine, for treatment of $C$. burnetii persistent focalized infection. Doxycycline plus hydroxychloroquine are the gold standard treatments for $C$. burnetii endocarditis. Treatment duration is recommended for 18 months for natural valve or vascular $C$. burnetii infection without prosthetic material, and 24 months in the presence of prosthetic material[ ${ }^{[2,3,21]}$. A combination of doxycycline with hydroxychloroquine was also chosen in our case for two years. The treatment period was uneventful.

The review of published articles in countries close to our geographic revealed that Elzein et al. ${ }^{[22]}$ reported 19/234 (8.10\%) 
0 fever endocarditis cases in BCNIE, 10-year experience in Saudi Arabia. All patients had been treated with a combination of hydroxychloroquine and doxycycline. A study in France by Houpikian and Raoult ${ }^{[23]}$ examined 348 cases with BCNIE and revealed 167 (48\%) cases as 0 fever endocarditis. In Bulgaria, a total of five cases of endocarditis were reported, three of these before 1990, 1 in 1996, and 1 in 1997 ${ }^{[24]}$. In Iran, Moradnejad et al. ${ }^{[25]}$ reported 16/52 (30.77\%) 0 fever endocarditis cases in BCNIE. As far as we know, there are published two cases in our country. Şimşek Yavuz et al. ${ }^{[26]}$ have reported the first case of a chronic $\mathrm{Q}$ fever endocarditis and aortitis from Turkey. That case had multiple operations due to valvulopathy due to chronic 0 fever endocarditis. The patient developed aortic graft infection, sternal osteomyelitis, and mediastinitis and died despite proper treatment and surgical intervention. Sonsöz et al. ${ }^{[27]}$ reported a case of acute endocarditis in a 35-year-old patient who had constitutional symptoms for a month. In our case, the duration from onset of symptoms to the treatment and surgical intervention was approximately two months. He presented with persistent fever, severe congestive heart failure, elevated liver enzymes, prolonged international normalized ratio, and ascites; however, he improved shortly after proper treatment and surgical intervention. Early diagnosis, treatment, and surgical intervention are important from the point of complications, mortality, and survey.

\section{Conclusion}

Chronic 0 fever is usually manifested by endocarditis, a rare, severe, and fatal complication of $C$. burnetii infection. Clinicians should be aware of this rare disease in patients with unexplained prolonged fever, hepatosplenomegaly, and increased ESR and CRP.

\section{Ethics}

Informed Consent: Consent form was filled out by a participant.

Peer-review: Externally peer-reviewed.

\section{Authorship Contributions}

Concept: S.A., Design: S.A., Data Collection or Processing: S.A., Analysis or Interpretation: S.A., Literature Search: S.A., Writing: S.A., O.D., M.Y.

Conflict of Interest: No conflict of interest was declared by the authors.

Financial Disclosure: The authors declared that this study received no financial support.

\section{References}

1. Mori $\mathrm{M}$, Roest HJ. Farming, $\mathrm{Q}$ fever and public health: agricultural practices and beyond. Arch Public Health. 2018;76:2.
2. Eldin C, Mélenotte $C$, Mediannikov O, Ghigo E, Million M, Edouard S, Mege JL, Maurin M, Raoult D. From Q Fever to Coxiella burnetii Infection: a Paradigm Change. Clin Microbiol Rev. 2017;30:115-90.

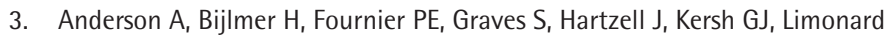
G, Marrie TJ, Massung RF, McQuiston JH, Nicholson WL, Paddock CD, Sexton DJ. Diagnosis and management of $\mathrm{O}$ fever--United States, 2013: recommendations from $\mathrm{CDC}$ and the 0 Fever Working Group. MMWR Recomm Rep. 2013;62:1-30.

4. Kavuncuoğlu D, Koşan Z. Coxiella (Q Fever): Epidemiology. In: Parlak M (ed) Coxiella(Q Ateşi) 1.baskı ed. Ankara: Türkiye Klinikleri, 2021:1-6.

5. Cikman A, Aydin M, Gulhan B, Karakecili F, Ozcicek A, Kesik OA, Parlak M, Ozcelik F, Gültepe B. The seroprevalence of Coxiella burnetii in Erzincan, Turkey: Identification of the risk factors and their relationship with geographical features. J Vector Borne Dis. 2017;54:157-63.

6. Seyitoğlu Ş, Özkurt Z, Dinler U, Okumuş B. The seroprevalence of Coxiellosis in farmers and cattle in Erzurum district in Turkey. Turk J Vet Anim Sci. 2006;30:71-5

7. Aslan $M H_{1}$ Ayyıldız A. Erzurum, Kars ve Ardahan illerindeki süt ve süt ürünleri üreticilerinde 0 ateşi seroprevalansının araştırılması. Kocatepe Tıp Dergisi. 2020;21:64-9.

8. Büke $C$, Atalay $\mathrm{S}$, Tunçel $\mathrm{M}$, Arsu $\mathrm{G}$, Çiçeklioğlu M, Türk M. İzmir'in Ovacık beldesi'nde 0 humması seroprevalansının kesitsel değerlendirilmesi. Infeksiyon Dergisi. 2006;20:155-8.

9. Georgiev M, Afonso A, Neubauer $H$, Needham $H$, Thiery R, Rodolakis A, Roest H, Stark K, Stegeman J, Vellema P, van der Hoek W, More S. Q fever in humans and farm animals in four European countries, 1982 to 2010. Euro Surveill. 2013;18:20407.

10. Ebato M. Blood Culture-Negative Endocarditis. Advanced Concepts in Endocarditis, 2018.

11. Berberoğlu U, Gözalan A, Kiliç S, Kurtoğlu D, Esen B. [A seroprevalence study of Coxiella burnetii in Antalya, Diyarbakir and Samsun provinces] Mikrobiyol Bul. 2004;38:385-91.

12. Tozer SJ, Lambert SB, Sloots TP, Nissen MD. Q fever seroprevalence in metropolitan samples is similar to rural/remote samples in Queensland, Australia. Eur J Clin Microbiol Infect Dis. 2011;30:1287-93.

13. Khalili M, Mosavi M, Diali HG, Mirza HN. Serologic survey for Coxiella burnetii phase II antibodies among slaughterhouse workers in Kerman, southeast of Iran. Asian Pac J Trop Biomed. 2014;4(Suppl 1):S209-S12.

14. Karabay 0, Kocoğlu E, Baysoy G, Konyalıoğlu S. Coxiella burnetii seroprevalence in the rural part of Bolu, Turkey. Turk J Med Sci. 2009;39:641-5.

15. Eyigör M, Kırkan Ş, Gültekin B, Yaman S, Tekbıyık S, Aydın N. $Q$ humması için risk gruplarında Coxiella burnetii'ye karșı oluşan antikorların ELISA ve IFA testleri ile saptanması. Infeksiyon Dergisi. 2006;20:31-6.

16. Sertpolat M, Karakartal G. İzmir ve çevresindeki sağlıklı kan vericilerinde Coxiella burnetii seroprevelansının indirekt immünfloresan antikor testi ile araştırılması. İnfeksiyon Dergisi. 2005;19:419-23.

17. Kilic S, Yilmaz GR, Komiya T, Kurtoglu Y, Karakoc EA. Prevalence of Coxiella burnetii antibodies in blood donors in Ankara, Central Anatolia, Turkey. New Microbiol. 2008;31:527-34.

18. van der Hoek $W$, Versteeg B, Meekelenkamp JC, Renders NH, Leenders AC, Weers-Pothoff I, Hermans MH, Zaaijer HL, Wever PC, Schneeberger PM. Follow-up of 686 patients with acute 0 fever and detection of chronic infection. Clin Infect Dis. 2011;52:1431-6.

19. Brouqui $P$, Dupont HT, Drancourt $M$, Berland $Y$, Etienne J, Leport $C$, Goldstein F, Massip P, Micoud M, Bertrand A. Chronic 0 fever. Ninety-two cases from France, including 27 cases without endocarditis. Arch Intern Med. 1993;153:642-8

20. Barten DG, Delsing CE, Keijmel SP, Sprong T, Timmermans J, Oyen WJ, Nabuurs-Franssen MH, Bleeker-Rovers CP. Localizing chronic 0 fever: a challenging query. BMC Infect Dis. 2013;13:413. 
21. Melenotte $C$, Million M, Raoult D. New insights in Coxiella burnetii infection: diagnosis and therapeutic update. Expert Rev Anti Infect Ther. 2020;18:75-86.

22. Elzein FE, Alsherbeeni N, Alnajashi K, Alsufyani E, Akhtar MY, Albalawi R, Albarrag AM, Kaabia N, Mehdi S, Alzahrani A, Raoult D. Ten-year experience of $\mathrm{Q}$ fever endocarditis in a tertiary cardiac center in Saudi Arabia. Int J Infect Dis.. 2019;88:21-6.

23. Houpikian $P$, Raoult D. Blood culture-negative endocarditis in a reference center: etiologic diagnosis of 348 cases. Medicine (Baltimore). 2005;84:16273.

24. Serbezov VS, Kazár J, Novkirishki V, Gatcheva N, Kovácová E, Voynova V. 0 fever in Bulgaria and Slovakia. Emerg Infect Dis. 1999;5:388-94.
25. Moradnejad P, Esmaeili $S$, Maleki M, Sadeghpour A, Kamali M, Rohani M, Ghasemi A, Bagheri Amiri F, Pasha HR, Boudagh S, Bakhshandeh H, Naderi N, Ghadrdoost B, Lotfian S, Dehghan Manshadi SA, Mostafavi E. Q Fever Endocarditis in Iran. Sci Rep. 2019;9:15276.

26. Şimşek Yavuz S, Özbek E, Başaran S, Çelebi B, Yılmaz E, Başaran M, Umman $B$, Eraksoy $H$. The first case of chronic $Q$ fever endocarditis and aortitis from Turkey: A 5-year infection before diagnosis with drain in sternum. Anatol J Cardiol. 2016;16:814-6.

27. Sonsöz MR, Agüloğlu Bali E, Aydoğan M, Mercanoğlu F, Yavuz Ş. Q fever endocarditis: is it always subacute or chronic? Turk Kardiyol Dern Ars. Turk Kardiyol Dern Ars. 2020;48:72-6. 